\title{
Separation and recovery of organic acids from fermented kitchen waste by an integrated process
}

\author{
Farah Nadia Omar, Nor’Aini Abdul Rahman*, Halimatun Saadiah Hafid, Phang Lai Yee and \\ Mohd Ali Hassan
}

\begin{abstract}
Department of Bioprocess Technology, Faculty of Biotechnology and Biomolecular Sciences, University Putra Malaysia, 43400 Serdang, Selangor, Malaysia.

Accepted 4 September, 2009
\end{abstract}

\begin{abstract}
Organic acids produced from anaerobic digestion of kitchen waste were recovered using a new integrated method which consisted of freezing and thawing, centrifugation, filtration and evaporation. The main organic acid produced was lactic acid (98\%). After the freezing and thawing process, $73 \%$ of the total suspended solids were removed and the organic acids were elevated from 59.0 to $70 \mathrm{~g} / \mathrm{L}$. The evaporation technique was used to further concentrate the organic acids up to $224 \mathrm{~g} / \mathrm{L}$. Using the integrated recovery method, the reduction of the total suspended solids in the solution achieved was about $93 \%$. The material balance for the recovery process was also presented.
\end{abstract}

Key words: Anaerobic digestion, kitchen waste, organic acids, recovery.

\section{INTRODUCTION}

The remarkable growth economy in Malaysia has brought tremendous population growth which then resulted in a huge amount of municipal solid waste (MSW) being generated throughout the year. MSW is usually dumped in landfills and degraded into simpler compounds. However, due to the scarcity of land and the constraint of landfill areas, alternative methods should be considered in order to reduce the space needed for landfills. Incineration is also an option (Ohkouchi and Inoue, 2006) as it is an easy final disposal method but large amounts of energy will be wasted in the burning process (Tsai, 2008). Since $22-54 \%$ of MSW consists of food and organic wastes (Kathirvale et al., 2003), bioconversion of MSW into useful products is feasible and its treatment cost can be reduced too.

Food waste contains about $80 \%$ of moisture which is easily biodegradable and is rich in nutrients and microflora (Wang et al., 2001). Due to these characteristics, biological treatments are preferred. One of the most practical biological treatments is anaerobic digestion. It is a great tool to stabilize a large volume of waste materials economically and effectively (Sakai et al., 2000). It also

*Corresponding author. E-mail: nor_aini@biotech.upm.edu.my. Tel.: 6038946 6669. Fax: 60389467510. produces low biomass and is able to destroy pathogens (Banarjee et al., 1999). Food waste could be anaerobically fermented to produce volatile fatty acids, aldehydes, alcohols and carbon dioxide (Stabnikova et al., 2006). Rather than being degraded and unexploited in the landfills, food waste can be utilized for many applications such as the production of bioplastics (Sakai et al., 2004), biogas (Zhu et al., 2008), biohydrogen and ethanol productions (Kim et al., 2004), composting (Tsai, 2008; Adhikari et al., 2008) and organic acids production (Ohkouchi and Inoue, 2007; Zhang et al., 2008).

Organic acids are organic compounds which have been extensively used in the food and beverages industries, pharmaceutical industries, cosmetics, and detergents and recently they are extensively used for biopolymer production (Sauer et al., 2008). There are two ways to produce organic acids which are chemical synthesis or biological synthesis (Altaf et al., 2007). Whether it is chemically or biologically synthesized, the critical stage of the process is product recovery. Downstream processes including separation, extraction and purification of organic acids which contribute more than $60 \%$ of the overall production cost (Han et al., 2000). Several methods have been reported for extracting organic acids from the fermentation broth such as electrodialysis (Huang et al., 2007), membrane filtration (Kang and Chang, 2005), solvent extraction (Harington 
Fermented kitchen waste

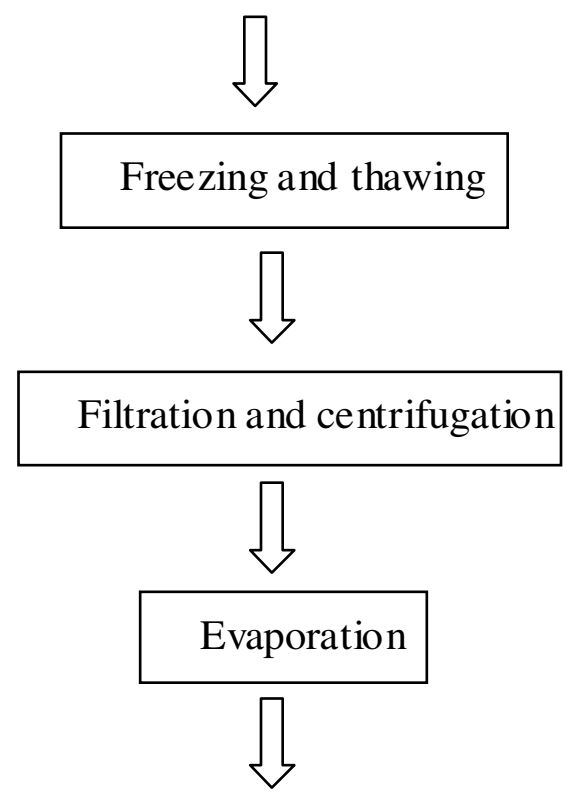

Concentrated Acids

Figure 1. Recovery process of organic acids from kitchen waste organic acids.

and Hossain, 2008), precipitation, adsorption on resins (Cao et al., 2002) as well as crystallization. Physical separations such as filtration and evaporation are widely used as organic acids recovery strategies (Mumtaz et al., 2008). However, those methods suffer a few problems like the usage of chemicals, production of large volume of wastes, high product loss and high power consumption. Freezing and thawing is a conventional method but yet is still being applied nowadays. It can improve sludge dewatering characteristics (Chu et al., 1999), transform the floc structure into more compact form (Kawasaki and Matsuda, 1995), reduces the sludge bound water content (Lee and Hsu,1994), as well as removes the suspended solids effectively (Phang et al., 2002). Thus, the aim of this study was to evaluate the performance of an integrated recovery process for organic acids from fermented food waste. A material balance for the recovery process is also presented in this paper.

\section{MATERIALS AND METHODS}

\section{Anaerobic digestion of food wastes}

Fresh food wastes were collected from local cafés and restaurants in Sri Serdang, Selangor, Malaysia. Fermentation was conducted using a $50 \mathrm{~L}$ stirred tank bioreactor. About $15 \mathrm{~kg}$ of food wastes were ground with heavy duty Waring blender. Fifteen liters of water was added in order to adjust the ratio of kitchen waste to water to be $1: 1$. The fermentation conditions were controlled at $37^{\circ} \mathrm{C}$ (Sakai and Ezaki, 2006) with agitation of 150rpm. Fermentation was carried out for seven days. Samples were collected daily and subjected to analyses.

\section{Recovery of organic acid from fermentation broth}

Figure 1 shows the recovery process of organic acids from fermented kitchen waste. The freezing and thawing method was performed according to Phang et al. (2002) with some modification. The freezing process was carried out using a deep freezer at $-30^{\circ} \mathrm{C}$ for overnight. The thawing process was conducted in a drying oven with temperature controlled at $60^{\circ} \mathrm{C}$ for $2-3 \mathrm{~h}$. The frozen sample was thawed on a cloth mesh with the pore size of $1.0 \mathrm{~mm}$. The filtrate was then centrifuged $(10000 \mathrm{~g}$ for $15 \mathrm{~min})$ and filtered $(0.8$ $\mu \mathrm{m}$, cellulose acetate filter paper) by using a vacuum pump filter. Evaporation was carried out by using a rotary evaporator (Büchi Rotavapor R-200, Swiss) (Mumtaz et al., 2008) until the desired concentration of the organic acids was achieved. Samples were collected at each recovery stage and subjected to analyses.

\section{Analytical methods}

Total suspended solids, Total Kjeldahl Nitrogen (TKN) and Chemical Oxygen Demand (COD) were determined according to the Standard Methods (APHA, 1985). Samples were centrifuged at $4000 \mathrm{~g}$ for $15 \mathrm{~min}$. Supernatant was filtered with $0.45 \mu \mathrm{m}$ syringe filter prior to organic acids determination. The organic acids concentration was measured by high performance liquid chromatography (SPD-10A, UV-VIS Detector, LC-10AS Liquid Chromatography Shimadzu, Japan) with ion exclusion HPLC Organic Acid Analysis Column (Aminex HPX-87H), $300 \mathrm{~mm} \times 7.8 \mathrm{~mm}$, Bio-Rad Laboratories and $4 \mathrm{mM} \mathrm{H}_{2} \mathrm{SO}_{4}$ was used as the mobile phase (Oh et al., 2005). Plate count method was done to measure viable bacterial count in the fermentation broth.

\section{RESULTS}

\section{Anaerobic digestion of kitchen wastes}

Figure 2 shows the total organic acids produced from the fermentation in a $50 \mathrm{~L}$ bioreactor. The highest production of organic acids was achieved at day $3(56.75 \mathrm{~g} / \mathrm{L})$ where it comprised of $57.6 \mathrm{~g} / \mathrm{L}$ of lactic acid. Acetic acid produced was relatively low during the fermentation process. The highest acetic acid production was observed at day 6 $(10.1 \mathrm{~g} / \mathrm{L})$. The production of organic acids was high until it started decreasing at day 7 . The kitchen waste fermentation was done without any $\mathrm{pH}$ adjustment. Figure 3 shows the profile of $\mathrm{pH}$ and bacterial distribution during kitchen waste fermentation. The $\mathrm{pH}$ of the broth on the first day was $\mathrm{pH} 6$ while the viable cells number recorded was $1.95 \times 10^{8} \mathrm{cfu} / \mathrm{mL}$. The $\mathrm{pH}$ decreased gradually until day 4 of fermentation. On day 4 onwards, the $\mathrm{pH}$ was maintained at $\mathrm{pH} 3$ and this was due to the accumulation of organic acids in the bioreactor. On the other hand, the viable cells number started to increase until it reached the maximum value on the third day $\left(4.5 \times 10^{8} \mathrm{cfu} / \mathrm{mL}\right)$ and then decreased until the end of fermentation. The total suspended solids patterns were monitored throughout the fermentation. During the fermentation, the total suspended solids decreased gradually with time (data not 


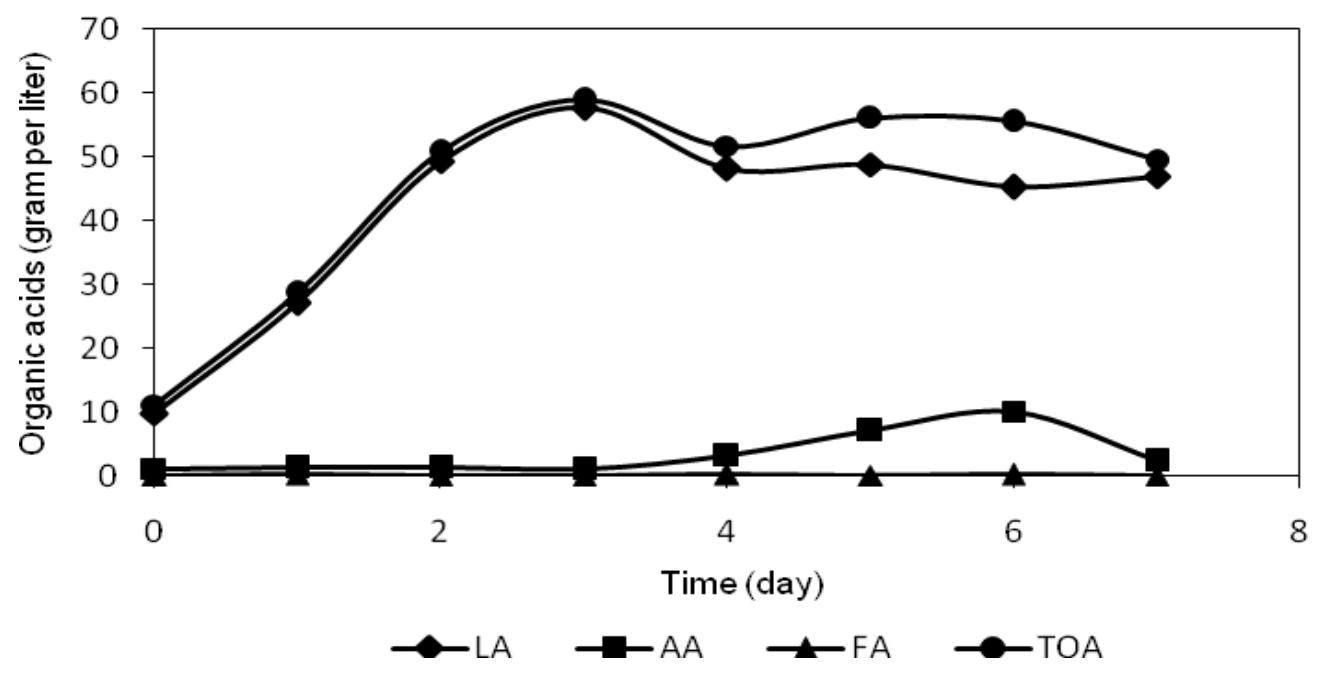

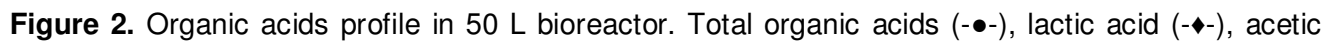
acid (- - -) and formic acid (- $\mathbf{\Delta}-)$. Results are means for duplicate experiments.

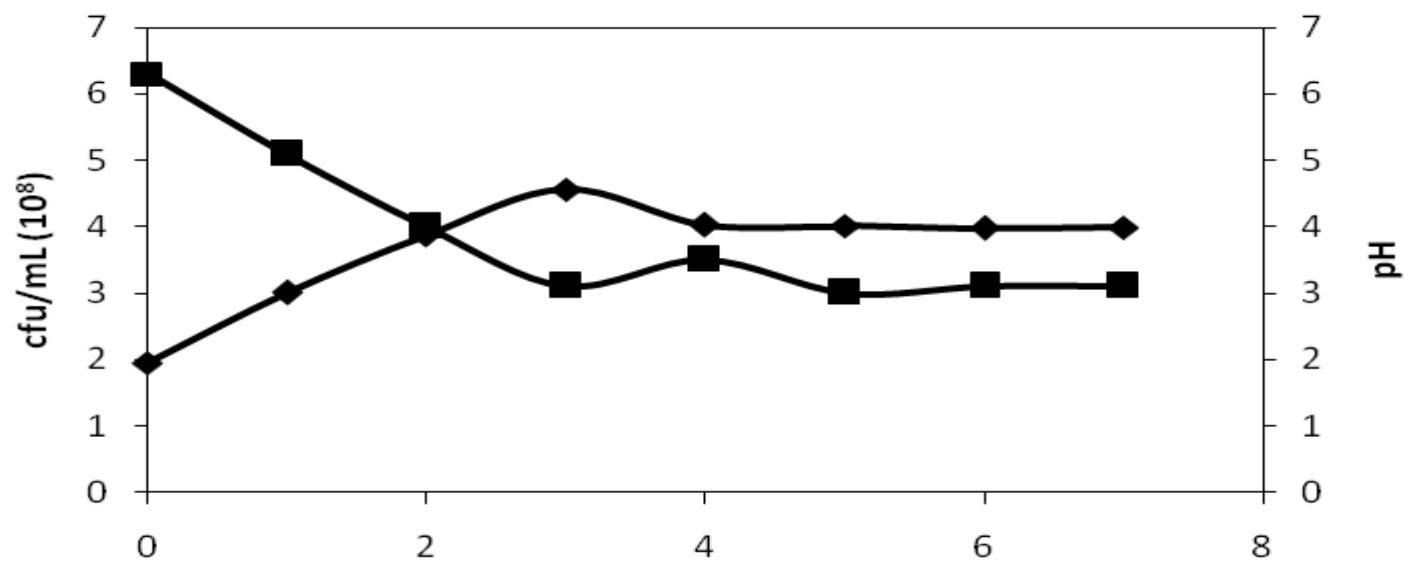

Time (day)

Figure 3. Profile of $\mathrm{pH}(-\mathbf{m}-)$ and bacteria distribution (- -$)$ during kitchen waste fermentation. Results are means for duplicate experiments.

shown). After seven days of fermentation, total suspended solids were reduced at $62 \%$.

\section{Organic acids recovery and total suspended solids reduction}

Figure 4 shows the organic acids, total suspended solids and Total Kjeldahl Nitrogen obtained at each unit operation of the recovery process. The recovery process includes physical separation that is freezing and thawing, centrifugation and filtration while the evaporation step is a method used to concentrate the recovered organic acids by eliminating excess water. The organic acids content increased by about $56 \%$ while the total suspended solids decreased by about $62.2 \%$ after the fermentation. By the freezing and thawing process, the organic acids content increased by $16 \%$ with $66 \%$ removal of total suspended solids. The centrifugation and filtration process do not have an effect on the concentration of the organic acids. The total suspended solids decreased from 17.89 to $12.27 \mathrm{~g} / \mathrm{L}$. Water was evaporated at $50^{\circ} \mathrm{C}$ in vacuum and the remaining organic acids and some suspended solids were concentrated. After the evaporation step, both the organic acids and the total suspended solids contents were increased by 69 and $83 \%$, respectively.

The nitrogen content of the fermentation broth and recovered liquid medium were analyzed in this study. The 
OA: $25.7 \mathrm{~g} / \mathrm{L}$

(HLa: $24 \mathrm{~g} / \mathrm{L}, \mathrm{HAc}: 1.7 \mathrm{~g} / \mathrm{L}$

OA: $59.0 \mathrm{~g} / \mathrm{L}$

(HLa: $57.9 \mathrm{~g} / \mathrm{L}, \mathrm{HAc}: 1.1 \mathrm{~g} / \mathrm{L}$ )

OA: $70.0 \mathrm{~g} / \mathrm{L}$

(HLa: $64.7 \mathrm{~g} / \mathrm{L}, \mathrm{HAc:} 5.3 \mathrm{~g} / \mathrm{L}$ )

OA: $70.3 \mathrm{~g} / \mathrm{L}$

(HLa: $65 \mathrm{~g} / \mathrm{L}, \mathrm{HAc:}$ 5.3g/L)

OA: $223.9 \mathrm{~g} / \mathrm{L}$

(HLa: $210 \mathrm{~g} / \mathrm{L}, \mathrm{HAc}: 13.9 \mathrm{~g} / \mathrm{L}$ )

\section{KITCHEN WAS TE (DAY 0)}<smiles>[CH]C</smiles>

KITCHEN WAS TE (DAY 7)

$\downarrow$

FREEZING \& THAWING

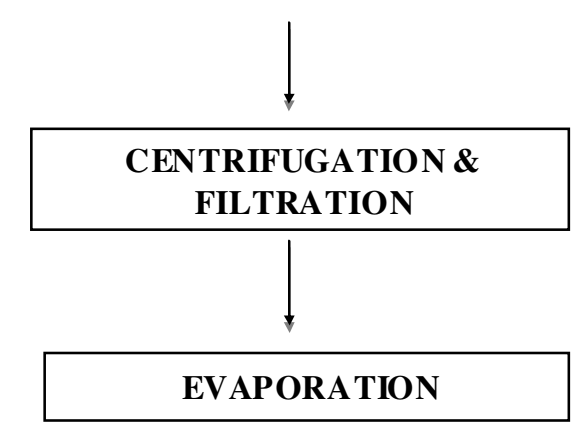

$\downarrow$
TSS: $179.99 \mathrm{~g} / \mathrm{L}$

TKN: $20.1 \%$

TSS: $67.95 \mathrm{~g} / \mathrm{L}$

TKN: $0.42 \%$

TSS: $17.89 \mathrm{~g} / \mathrm{L}$

TKN: $0.31 \%$

TSS: $12.27 \mathrm{~g} / \mathrm{L}$

TKN: $0.23 \%$

TSS: $70.12 \mathrm{~g} / \mathrm{L}$

TKN: $1.2 \%$

\section{CONCENTRATED ACIDS}

Figure 4. Organic acids (OA); lactic acid (HLa), acetic acid (HAc) concentration, Total Kjeldahl Nitrogen (TKN) and Total Suspended Solids (TSS) obtained at each unit operation of the recovery processes.

initial nitrogen content in the kitchen wastes was $20.1 \%$ and after seven days of fermentation, the nitrogen reduced to about $94 \%$. After the freezing and thawing process, the TKN was not much reduced $(0.11 \%)$. By filtration, the TKN reduction observed was only about $0.23 \%$, suggesting that nitrogen molecules would not be retained on the filter paper. Finally, after evaporation the organic acids content and TKN increased. A clear brownish solution containing $200 \mathrm{~g} / \mathrm{L}$ organic acids was successfully recovered through this integrated method. The organic acids recovered can be used as fermentation feedstock for production of value-added products.

\section{DISCUSSION}

\section{Anaerobic digestion of kitchen wastes}

Lactic acid was the main organic acid produced (98\%) followed by acetic acid (1.8\%) and formic acid (0.2\%). The same phenomenon was also observed by Sakai and Ezaki (2006), Zhang et al. (2007) and Kim et al. (2008) whereby lactic acid was predominant organic acid produced in the kitchen waste fermentation. There were a few factors which affect the production of lactic acid in the anaerobic digestion process such as inoculum, substrate characteristics, $\mathrm{pH}$ and temperature (Zhang et al., 2008). Kitchen waste contains a lot of active indigenous microbes where it exerts significant roles in converting large molecules into simpler molecules (Wang et al., 2005). The viable cell numbers were increased at the first 3 days of fermentation and this concomitant with the increased of organic acids production. The accumulation of organic acids resulted in the reduction of $\mathrm{pH}$ value in the bioreactor. The microbe seems accommodated well in the complex substrates of kitchen waste. Based on the nucleotide sequences of the microbial community, there were a variety of lactic acid bacteria and a small community of Clostridium sp. as well as Bacillus coagulans present in the original food waste (Zhang et al., 2008). Sakai et al. (2000) also reported that the dominant bacteria isolated from the food refuse fermentation were identified as Lactobacillus plantarum and Lactobacillus brevis. Most lactate producing bacteria are able to grow in a broad $\mathrm{pH}$ range from 3.5 to 9.0 while $B$. coagulans favor narrower $\mathrm{pH}$ range of 5.0 to 7.0 (Sakai and Ezaki, 2006). In order to obtain high lactic acid production, anaerobic digestion of kitchen waste in this study was performed at $37^{\circ} \mathrm{C}$ as most lactic acid producers as well as indigenous microbes in the kitchen waste favor that 
condition (Sakai and Ezaki, 2006). Kitchen waste contains high levels of organic compounds, nutrients, carbohydrates, fat and protein. The carbohydrate will be degraded into smaller compounds like sucrose, fructose, lactose and these simpler sugars can be easily taken up by indigenous acid-producing bacteria (Zhang et al., 2008). Ohkouchi and Inoue (2006) reported that a total of $58.5-81.8 \%$ carbohydrate in kitchen waste existed as starch. Thus, amylase will be highly expressed and this will result in a direct production of lactic acid from kitchen wastes. During the fermentation, the total suspended solids decreased gradually with time. The organic matter was first liquefied by extracellular enzymes (Banerjee et al., 1999). Substrate solubilization is a vital step in anaerobic digestion and it can be predicted from total suspended solids value. Apart from the substrate solubilization, the decreasing pattern of total suspended solids might be due to the consumption of the food wastes by the indigenous microbes. All the solids were degraded and converted to various products like organic acids, water, simple sugars, methane, hydrogen and carbon dioxide (Claassen et al., 1999).

\section{Organic acids recovery and total suspended solids reduction}

The recovery process includes physical separation that is freezing and thawing, centrifugation and filtration while the evaporation step is a method used to concentrate the recovered organic acids by eliminating excess water. After the fermentation, the organic acids content increased by about $56 \%$ while the total suspended solids decreased by about $62.2 \%$. Anaerobic digestion consists of a few stages including hydrolysis, acidogenesis, acetogenesis and methagonesis. Acidogenesis is involved in the breakdown of the simple sugars, fatty acids and amino acids by acidogenic bacteria into volatile fatty acids and produces ammonia, carbon dioxide and hydrogen sulfide as by-products (Stabnikova et al., 2006). By the freezing and thawing process, the organic acids content increased by $16 \%$ with $66 \%$ removal of total suspended solids. Phang et al. (2002) reported that $77 \%$ of suspended solids removal could be achieved for palm oil mill effluent by freezing and thawing. The suspended solids are separated when it is frozen in the ice during the freezing process. At the same time, the concentration process occurs and all the water molecules were bonded together by electrostatic attraction which makes it impossible for the other particles or molecules to be part of the ice crystals thus allowing them to be eliminated later (Martel, 2000). The centrifugation and filtration process do not have an effect on the concentration of the organic acids. The total suspended solids decreased from 17.89 to $12.27 \mathrm{~g} / \mathrm{L}$. Water was evaporated at $50^{\circ} \mathrm{C}$ in vacuum and the remaining organic acids and some suspended solids were concentrated. After the evaporation step, both the organic acids and the total suspended solids contents were increased by 69 and $83 \%$, respectively.

Besides carbon, nitrogen is also a critical substance in fermentation. The acid-producing bacteria in the kitchen waste require organic nitrogen source for organic acids production (Ohkouchi and Inoue, 2007). The initial nitrogen content in the kitchen wastes was $20.1 \%$ and after seven days of fermentation, the nitrogen reduced about $94 \%$. Zhang et al. (2008) reported that the nitrogen content in kitchen wastes was $17.8 \%$ while $\mathrm{Ma}$ et al. (2009) showed slightly lower total nitrogen in their kitchen waste $(15.56 \%)$. After the freezing and thawing process, the TKN was not much reduced $(0.11 \%)$. Freezing and thawing are physical methods for conditioning the sludge and for the removal of suspended solids (Phang et al., 2003) while filtration is also a physical method in removing the suspended solids. Evaporation is a method used to concentrate the organic acids through the removal of excess water (Mumtaz et al., 2008). After evaporation, the organic acids content and TKN increased. During the process, water was condensed, leaving a lesser volume of remaining solution. Therefore, the concentration of organic acids and TKN in the remaining solution increased three and five folds, respectively compared with the organic acids and TKN before the evaporation process. A clear brownish solution containing $200 \mathrm{~g} / \mathrm{L}$ organic acids was successfully recovered through this integrated method. The organic acids recovered can be used as fermentation feedstock for production of valueadded products.

\section{Material balance}

The material balance for the overall separation and recovery process is given in Figure 5 . By using a combination of physical separation, freezing and thawing and filtration, a total of $93 \%$ of the suspended solids were removed. During evaporation, almost $25 \%$ of water present in the broth was lost as vapor, 36\% was distillated and $37 \%$ as concentrated acids. From the overall experiment, the weight of total concentrated acids (223.9 $\mathrm{g} / \mathrm{L}$ ) that could be recovered from raw kitchen waste were about $20 \%(\mathrm{w} / \mathrm{w})$. Some improvements and modifications should be carried out such as the usage of sophisticated filtration system in order to attain higher concentrated acids.

\section{Conclusion}

Organic acids could be produced from anaerobic digestion of kitchen waste and were recovered by using freezing and thawing method in combination with centrifugation, filtration and evaporation methods. A total of $93 \%$ of total suspended solids from raw kitchen waste could 


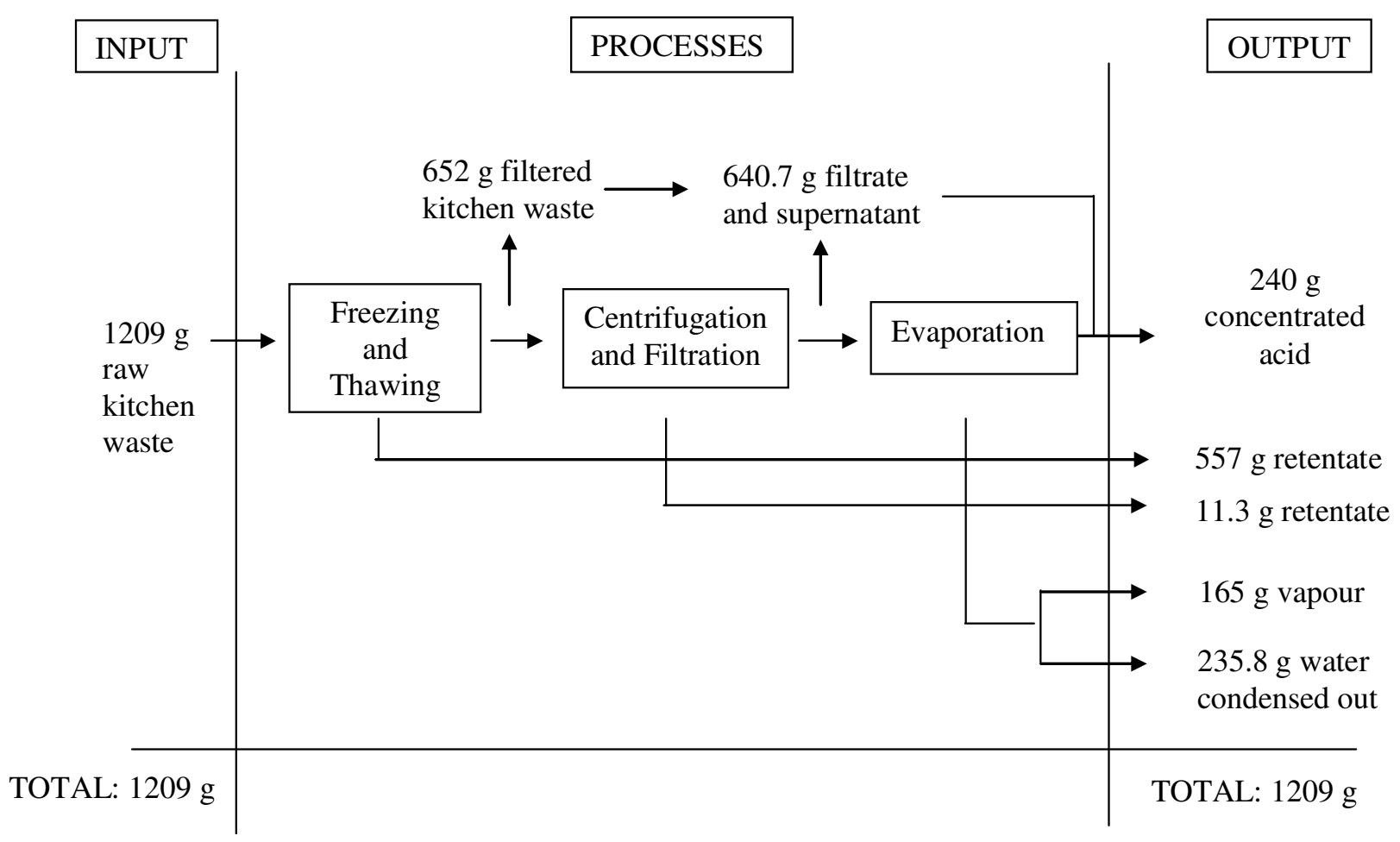

Figure 5. Material balance for the recovery of organic acids from fermented kitchen waste.

be removed by using freezing and thawing method and filtration methods. From the integrated recovery method developed, about $20 \%(\mathrm{w} / \mathrm{w})$ of total concentrated acids $(224 \mathrm{~g} / \mathrm{L})$ could be recovered from the raw fermented kitchen waste.

\section{ACKNOWLEDGEMENTS}

The authors would like to acknowledge the people of Malaysia and Ministry of Science and Technology and Innovation (MOSTI) for funding and technical support during the study period. A Graduate Research Fellowship from the University of Putra Malaysia (UPM), Malaysia to the main author also contributed to this research.

\section{REFERENCES}

APHA (1985). Standard Methods for the examination of water and wastewater $16^{\text {th }}$ ed. American Public Health Association, NY., USA.

Adhikari BK, Barrington S, Martinez J, King S (2008). Characterization of food waste and bulking agents for composting. Waste Manage. 28: $795-804$

Altaf M, Naveena BJ, Reddy G (2007). Use of inexpensive nitrogen sources and starch for $\mathrm{L}(+)$ lactic acid production in anaerobic submerged fermentation. Bioresour. Technol. 98: 498-503.

Banarjee A, Elefsiniotis P, Tuhtar D (1999). The effect of addition of potato-processing wastewater on the acidogenesis of primary sludge under varied hydraulic retention time and temperature. J. Biotechnol. 72: 203-212.

Cao X, Yun HS, Koo YM (2002). Recovery of L-(+)-lactic acid by anion exchange resin Amberlite IRA-400. Biochem. Engin. J. 11: 189-196. Chu CP, Feng WC, Bea-Ven C, Chou CH and Lee DJ (1999). Reduction of microbial density level in wastewater activated sludge via freezing and thawing. J. Water Res. 33(16): 3532-3535.

Claassen PAM, Van Lier JB, Lopez Contreras AM, Van Niel EWJ, Sijtsma L, Stams AJM, De Vries SS, Weusthuis RA (1999). Utilization of biomass for the supply of energy carriers. Appl. Microbiol. Biotechnol. 52: 741-755.

Han DH, Hong YK, Hong WH (2000). Separation characteristics of lactic acid in reactive extraction and stripping. Korean J. Chem. Eng. 17: 528-533.

Harington T, Hossain MM (2008). Extraction of lactic acid into sunflower oil and its recovery into an aqueous solution. Desalination, 218: 287296.

Hassan MN, Chong TL, Rahman M, Salleh MN, Zakaria Z, Awang M (2001). Solid Waste Management in Southeast Asian Countries with Special Attention to Malaysia. Proceedings Sardinia, $8^{\text {th }}$ International Waste Management and Landfill Symposium, Italy, 1-5 October.

Huang C, Xu T, Zhang Y, Xue Y, Chen G (2007). Review Application of electrodialysis to the production of organic acids: State-of-the-art and recent developments. J. Memb. Sci. 288: 1-12.

Kang SH, Chang YK (2005). Removal of organic acid salts from simulated fermentation broth containing succinate by nanofiltration. J. Memb. Sci. 246(1):49-57.

Kathirvale S, Muhd Yunus MN, Sopian K, Samsuddin AH (2003). Energy potential from municipal solid waste in Malaysia. Renewable Energy, 29: 559-567.

Kawasaki K, Matsuda A (1995). Effect of dissolved solid concentration on freezing and thawing of excess activated sludge. Kagaku Kogaku Ronbunsyu, 21: 859-865.

Kim SH, Han SK, Shin HS (2004). Feasibility of Biohydrogen production by anaerobic co-digestion of food waste and sewage sludge. Int. J. Hydrogen Energy 29:1607-1616.

Kim JK, Han GH, Oh BR, Chun YN, Eom CY, Kim SW (2008). Volumetric scale-up of a three stage fermentation system for food waste treatment. Bioresour. Technol. 99(10): 4394-4399. 
Lee DJ, Hsu YH (1994). Fast freeze/thaw treatment on activated sludge: Floc structure and sludge dewaterability. Environ. Sci. Technol. 28: 1444-1449.

Ma H, Wang Q, Qian D, Gong L, Zhang W (2009). The utilization of acid-tolerant bacteria on ethanol production from kitchen garbage. Renewable Energy, 34: 1466-1470.

Martel J (2000). Influence of Dissolved Solids on the Mechanisms of freeze-thaw conditioning. Water Res. 34: 657-662.

Mumtaz T, Abdul-Aziz S, Nor Aini AR, Phang LY, Shirai Y, Hassan MA (2008). Pilot-scale recovery of low molecular weight organic acids from anaerobically treated palm oil mill effluent (POME) with energy integrated system. Afr. J. Biotechnol. 21: 3900-3905.

Oh H, Young-Jung W, Jong-Sun Y, Seung-Ho H, Sangwon J, Hwa-Won $R$ (2005). Lactic acid production from agriculture resources as cheap raw material. Bioresour. Technol. 96: 1492-1498.

Ohkouchi Y, Inoue Y (2007). Impact of chemical components of organic wastes on $L(+)$-lactic acid production. Bioresour. Technol. 98: 546553.

Ohkouchi $\mathrm{Y}$, Inoue $\mathrm{Y}$ (2006). Direct production of $\mathrm{L}(+)$-lactic acid from starch and food wastes using Lactobacillus manihotivorans LMG18011. Bioresour. Technol. 97: 1554-1562.

Phang LY, Hassan MA, Shirai Y, Wakisaka M, Abdul Karim MI (2003). Continuous production of organic acids from palm oil mill effluent with sludge recycle by the freezing-thawing method. J. Chem. Eng. Jpn. 36(6): 707-710.

Phang LY, Wakisaka M, Shirai Y, Hassan MA (2002). Freezing and thawing technique for the removal of suspended solids and concentration of palm oil mill effluent (POME). J. Chem. Eng. Jpn. 35(10): 1017-1019.

Sakai K, Murata Y, Yamazumi H, Tau Y, Mori M, Moriguchi M, Shirai Y (2000). Selective proliferation of lactic acid bacteria and accumulation of lactic acid during open fermentation of kitchen refuse with intermittent $\mathrm{pH}$ adjustment. J. Food Sci. Technol. Res. 6(2): 140-145.

Sakai K, Taniguchi M, Miura S, Ohara H, Matsumoto T, Shirai Y (2004). making plastics from garbage: A novel process for poly-L-lactate production from municipal food waste. J. Ind. Ecol. 7(3,4): 63-74.
Sakai K, Ezaki Y (2006). Open L-Lactic Acid Fermentation of Food Refuse Using Thermophilic Bacillus coagulans and Fluorescence In Situ Hybridization Analysis of Microflora. J. Biochem. Bioeng. 101(6): 457-463.

Sauer M, Porro D, Mattanovich D, Branduard P (2008). Microbial production of organic acids: Expanding the markets. Trends in Biotechnol. 26: 100-109.

Stabnikova O, Liu XY, Wang JY (2006). Digestion of frozen/thawed food waste in the hybrid anaerobic solid-liquid system. Waste Manage. 28: 1654-1659.

Tsai WT (2008). Management considerations and environmental benefit analysis for turning food garbage into agricultural resources. Bioresour. Technol. 99: 5309-5316.

Wang Q, Yamabe K, Narita J, Morishita M, Ohsumi Y, Kusano K, Shirai Y, Ogawa HI (2001). Suppression of growth of putrefactive and food poisoning bacteria by lactic acid fermentation of kitchen waste. Proc. Biochem. 37: 351-357.

Wang XM, Wang QH, Ren NQ, Wang XQ (2005). Lactic acid production from kitchen waste with a newly characterized strain of Lactobacillus plantarum. J. Chem. Biochem. Eng. 19(4): 383-389.

Zhang B, Cai WM, He PJ (2007). Influence of lactic acid on the twophase anaerobic digestion of kitchen wastes. J. Environ. Sci. 19: 244-249.

Zhang B, Pin-jing H, Ning-fang Y, Li-ming S (2008). Enhanced isomer purity of lactic acid from the non-sterile fermentation of kitchen wastes. Bioresour. Technol. 99: 855-862.

Zhu H, Parker W, Basnar R, Proracki A, Falletta P, Beland M, Seto P (2008). Biohydrogen production by anaerobic co-digestion of municipal food waste and sewage sludges. Int. J. Hydrogen Energy, 33: 3651-3659. 